Vol. 122006 pp. 287-296

\author{
Jerzy Siwek \\ Chair of Cartography \\ E-mail: jrsiwek@uw.edu.pl
}

\title{
EVOLUTION OF SOZOLOGICAL MAPS IN POLAND
}

\begin{abstract}
The beginnings of sozological cartography in Poland go back to the second half of 1960s. Since those times many maps showing both relatively small areas and entire voivodships as well as the whole country have been published. A large range of territories corresponds to an equally large variation of the scale: from 1:10 000 and 1:25 000 scales to small scales in school atlases. The content of the individual maps exhibits a large differentiation - from the monothematic approaches to the richest in content, comprehensive 1:50 000 scale Sozological Map of Poland, published since the early 1990s. The state of the natural environment of Poland, presented on many detailed maps, still awaits a synthesis in form of general regional maps, thus of medium-scale maps.
\end{abstract}

Key words: sozological map, sozological cartography, environmental protection, environment degradation, map graphics

The beginnings of sozological cartography in Poland go back to the second half of 1960s and are connected with the work of Katarzyna Brykowicz and Krystian Waksmundzki (Institute of Geography of the Jagiellonian University) on the notion of a map presenting the issue of protection and formation of the geographic environment in a comprehensive way. This way the idea of the Czech J. S. Prohazka, developed in Poland by A. Wodiczko, was transferred to cartography. Already in the period between the World Wars both scientists pointed out the need to recognise nature protection as a separate discipline. The comprehensive approach to the sozological issues referred to a similar approach, used in the environmental research in Poland since the early $1950 \mathrm{~s}$. At that time researchers began to form principles of creation of detailed maps of various components of the environment: hydrographical, geomorphological and geological maps.

The first published map presenting the issues of sozology was probably the 1:1 000000 scale Bonitation map - zones of concentration of harmful phenomena in Cracow Voivodship, made by K. Waksmundzki in 1969 and published a year later in the popular scientific monthly "Problemy" (Fig. 1). It is a synthetic map, which was created by comparing phenomena affecting disadvantageously the natural environment and distinguishing on this basis 


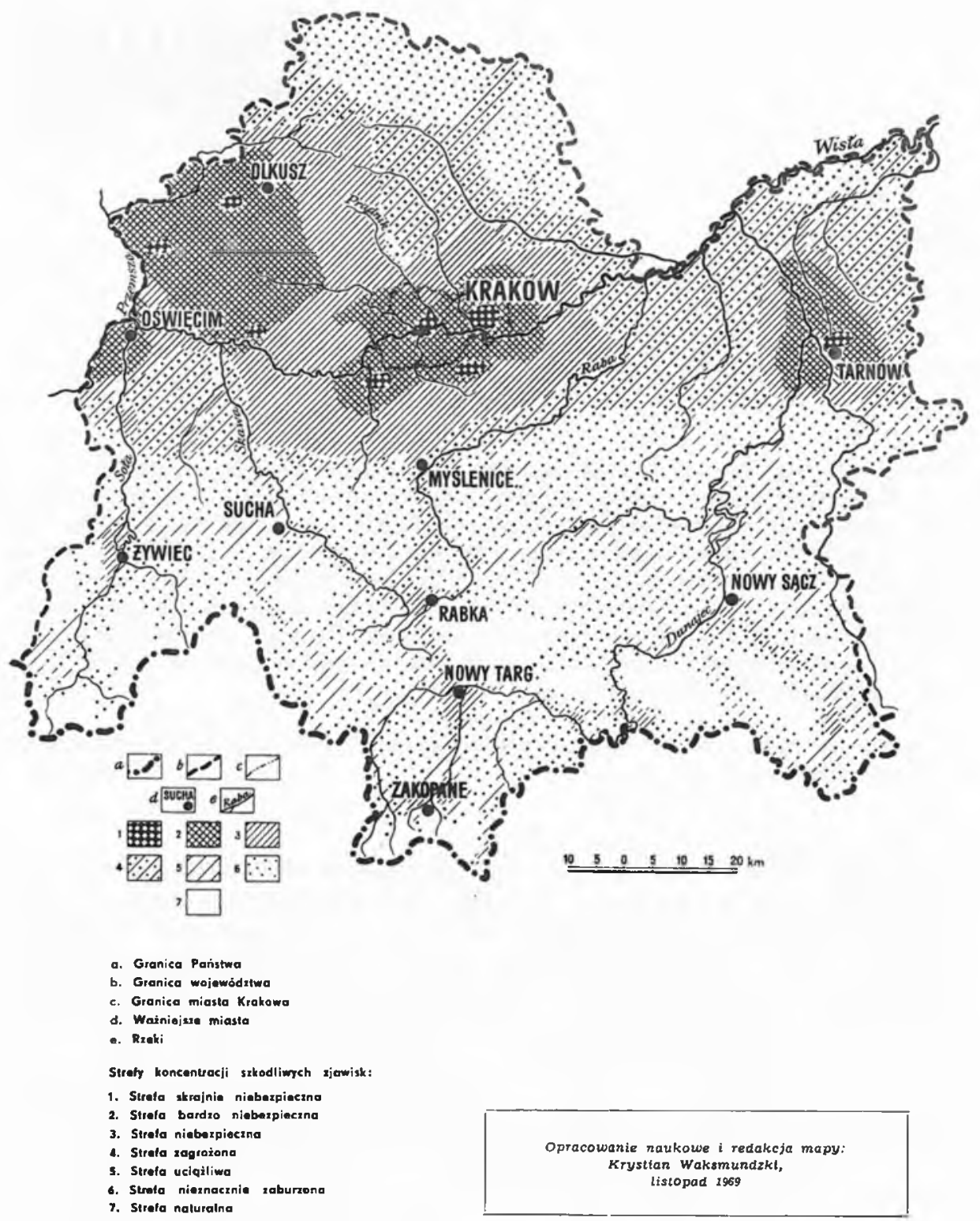

Fig. 1. Synthetic map showing concentration zones of phenomena degrading the natural environment in the Kraków region, scale 1:1 000000 (1970)

eight categories of areas with varying degree of its degradation (K. Brykowicz, K. Waksmundzki 1970).

Many sozological maps made in the 1970 s were hand-drawn. Mostly, atlas maps were published - small-scale maps, which served as the basis 


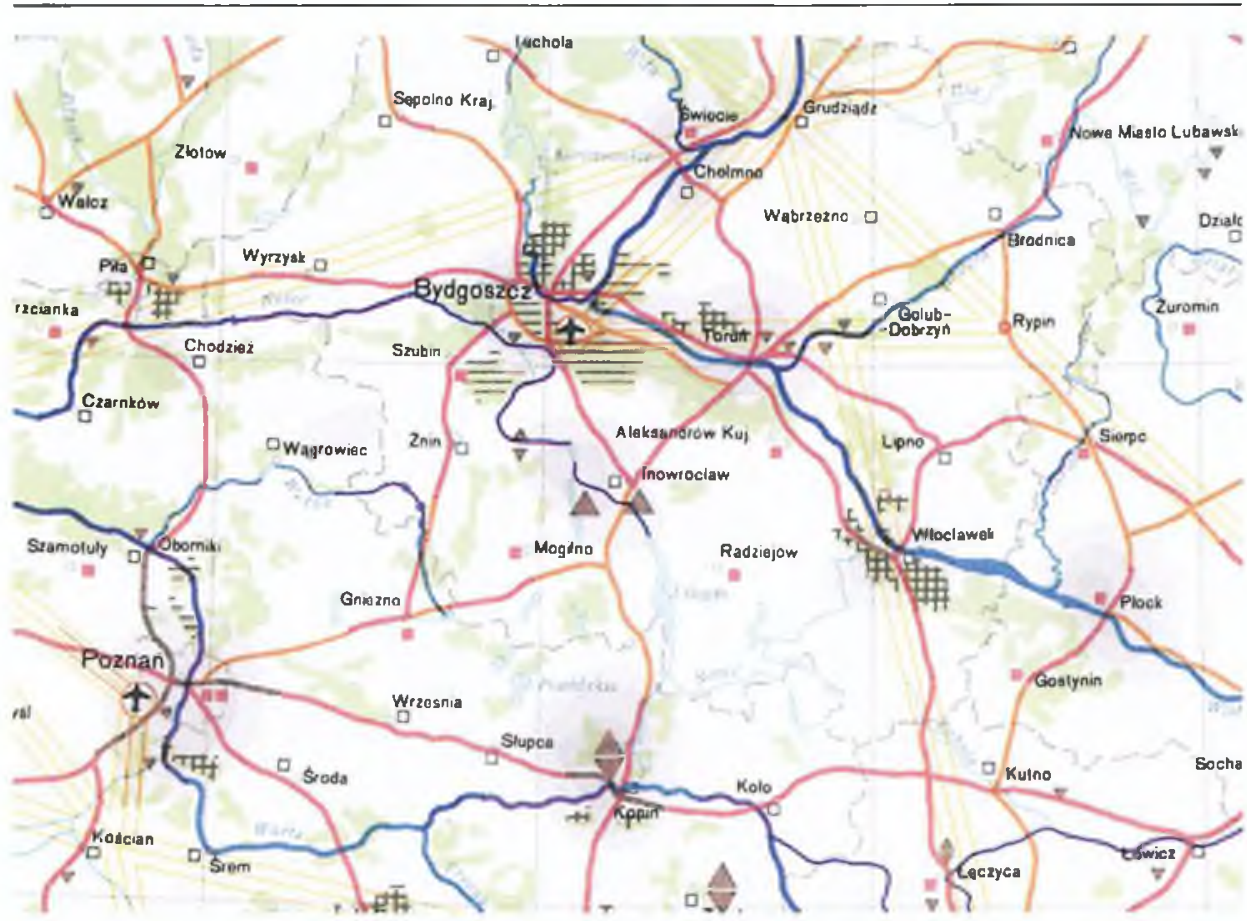

Fig. 2. Excerpt from the complex map "Environmental degradation and pollution", scale 1:2 000 000, National Atlas of Poland (1973-1978)

for the development of sozological cartography in Poland. Among pioneer achievements are four 1:1200 000 scale maps, included in the Atlas of Katowice Voivodship (1971) on the plate "Changes in Geographical Environment" and the 1:2000 000 scale map "Environmental Destruction and Pollution" in the National Atlas of Poland (1973-1978). The phenomena showed in both atlases are: anthropogenic transformation of the Earth surface and surface water and air pollution, but in the national atlas waste dumps, forest endangerment and noise were also included. This map can be thus regarded as the "prototype" of a comprehensive sozological map (Fig. 2).

Since the mid-1970s, sozological maps began to appear in school atlases of the State Cartographic Publishing House (Państwowe Przedsiębiorstwo Wydawnictw Kartograficznych, PPWK) - first in the Geographical Atlas of Poland (1974) (Fig. 3), and later in the atlas for the grades 6 through 8, entitled Poland, Continents, World (1977). The atlases contained issues illustrating natural protection and various forms of nature degradation. The introduction of map of this kind to school atlases started the popularisation of the sozological cartography and created an opportunity for a significant increase in social awareness of ecological problems. At that time, the work on the Atlas of Resources, Advantages and Dangers of the Geographical 


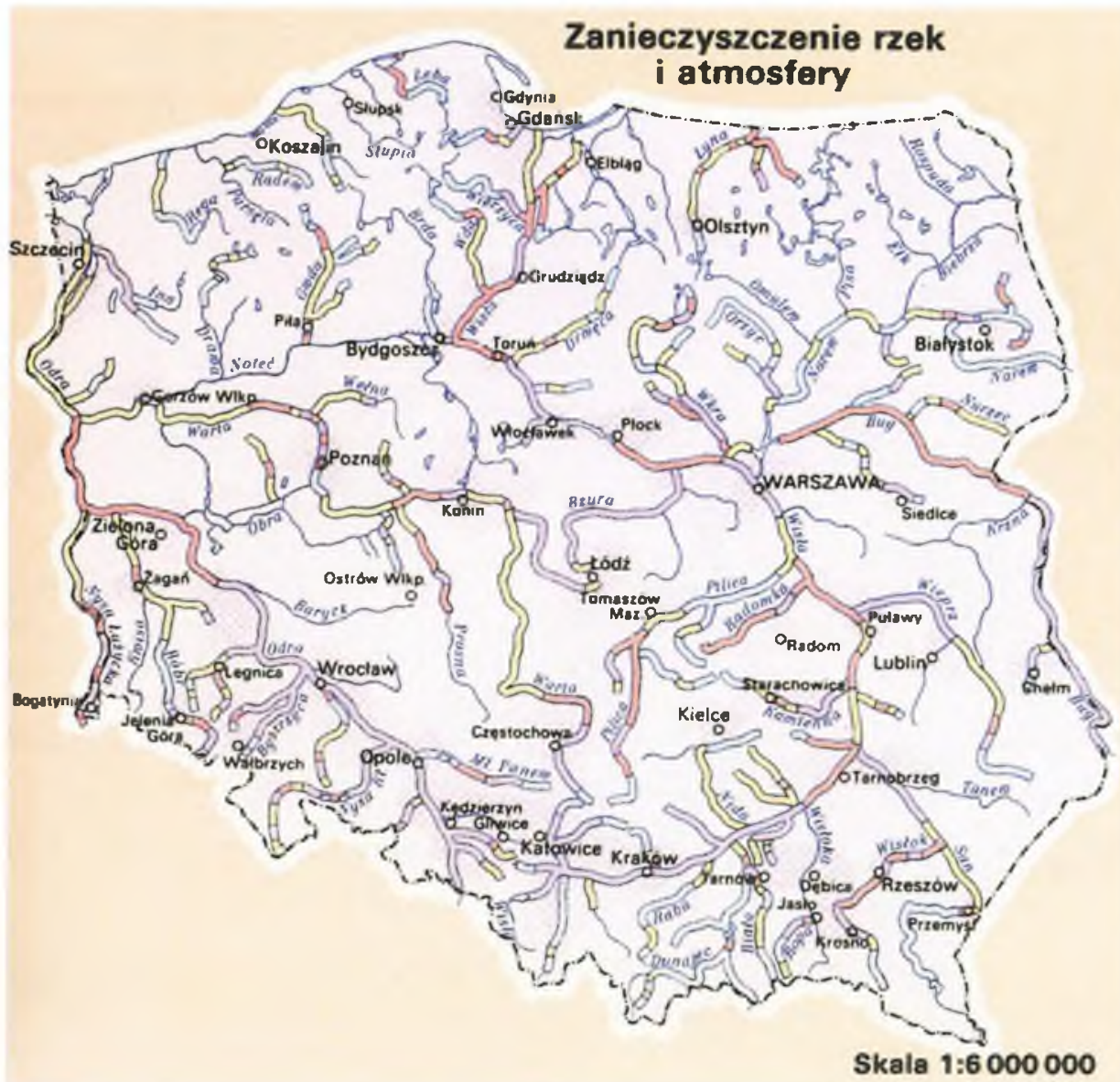

Fig. 3. One of two sozological maps, scale 1:6000 000, from the Geographical Atlas of Poland (1974)

Environment in Poland was in progress; the atlas was published as late as 1994, but it didn't met the expectations.

As B. Horodyski wrote (1983), maps published until the late 1970s "are characterised, in general, by simplification. They are often schematic, poor in content and not very accurate" (this was a result of the synthesis of meagre statistical and descriptive materials) "and the localisation of phenomena is often strongly deformed". Because of poorly worked out methodology of sozological maps "the scope of the [cartographical] methods used varies, and in general it is small".

The tendency to create general maps was continued in 1980s. At that time one could observe attempts to introduce certain standardisations, related mostly to the contents and less to its cartographic representation. Maps in three atlases of voivodships, made in the Cracow geographical centres, 
can be regarded as such attempts. After the City Atlas of Cracow Voivodship, published already in 1979, atlases of Bielsko (1981) and of Tarnów (1988) Voivodships were issued. They contained uniformly designed plates "Environmental Protection. Comprehensive Sozological Map". This title, somewhat misleading for the reader, refers to two 1:500 000 scale maps "Disturbances and Destruction of the Geographical Environment" and "Protection of the Greatest Values of the Geographical Environment" as well as to the 1:1 000000 scale bonitation map "Landscape Transformations". The first map showed the degradation of the basic elements of the environment: air, water, relief and vegetation and some forms of the degradation, e. g., waste dumps, noise and concentration of sulphur dioxide in the air (which was particularly stressed: six classes of concentration were shown). The second map presents various types of protected areas (among other things, national parks, nature reserves and natural monuments) and other areas valuable for humans (e. g., zones of clean air, soils of highest quality and protective forests). The standard of the sozological contents was introduced to the "Cracow" atlases, which was undoubtedly an advantage, although the authors did not succeed in introducing uniform cartographic symbols on all maps.

Among medium-scale maps from 1980s one should name the first monothematic map of the entire country entitled "Poland. Land Degradation", scale 1:500 000 (1983). The contents of this map consists of various lands transformed by mining and waste dumps, soils particularly vulnerable to degradation and degraded, as well as areas being degraded by pollutants emitted into the atmosphere. Large scope of information, in particular quantitative, together with the inappropriate form of presentation made this map into a "clinical" example of editorial mistakes.

The most serious initiatives regarding the standardisation of sozological maps were undertaken by the geographers from the A. Mickiewicz University in Poznan, in cooperation with the local geodesic-cartographic institution. The first project was the preparation of the fundamentals for a comprehensive 1:200 000 scale map of voivodships, whose sample sheet from the areas of Leszno Voivodship was published in 1986. Although this map was mot made for other voivodships, its concept was used somewhat later, in the work on the 1:50 000 scale Sozological Map of Poland.

Detailed sozological maps began to appear with a certain delay as compared with general maps. This followed from the lack of principles of conducting fieldwork, which was the basis for gathering of data and from the limitations imposed by the censorship. existing in Poland in the publication of large-scale maps until the end of 1980 s. One of the first maps was the 1:50 000 map "Air Pollution", included as "classified" in the Atlas of Warsaw (1975). It is well thought out as regards the methodology, although somewhat difficult to read because of the use of the logarithmic scale, according to which the size of the diagrams presenting the value of dust emission into atmosphere changes. 

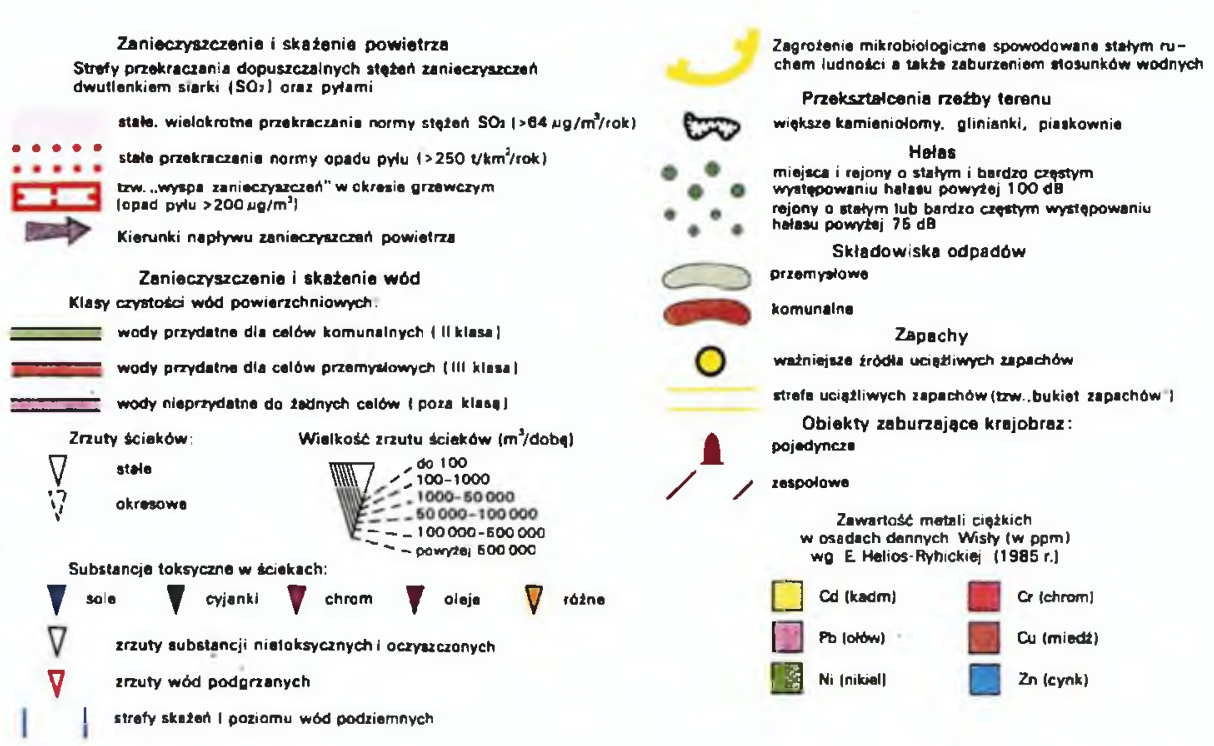

Fig. 4. Legend for the complex map "Environmental degradation and pollution", scale 1:50 000 from The Kraków Atlas (1988)

The so-called sozological atlases of the cities of the Upper Silesian Industrial District (Górnośląski Okręg Przemysłowy, GOP) can be regarded as an attempt to create a general model of large-scale sozological maps. The series began in 1982 with the publication of the atlas of the city of Sosnowiec. Each atlas consists of loose 1:10 000 scale maps, showing the summary indicator of air pollution, elements of water supply and sewage disposal and green areas together with the transformations of Earth surface as well as 1:50 000 scale maps demonstrating the contents of 18 harmful substances in the air and dust fall (A. Jankowski, J. Zieliński 1986). The GOP atlases present the most essential sozological issues encountered in strongly industrialised urban areas, but they don't exhaust the subject matter. The inventory character of the maps and their large scales didn't create problems of cartographic nature.

The comprehensive presentation of the contents on the 1:50 000 scale map "Degradation and Pollution of the Environment" in the Atlas of the City of Cracow (1988) constitutes an opposite approach to the analytical one used in the GOP atlases. The presentation of the sewage discharge, taking into account its quantity and the kinds of toxic substances contained in it (Fig. 4) was a novelty. This remarkable example of a sozological map of an urban area wasn't, however, used as a model for other projects. This map was three years ahead of the publication of the first sheets of the 1:50 000 scale Sozological Map of Poland, which opened a new period of domination of detailed sozological maps, lasting until today. 

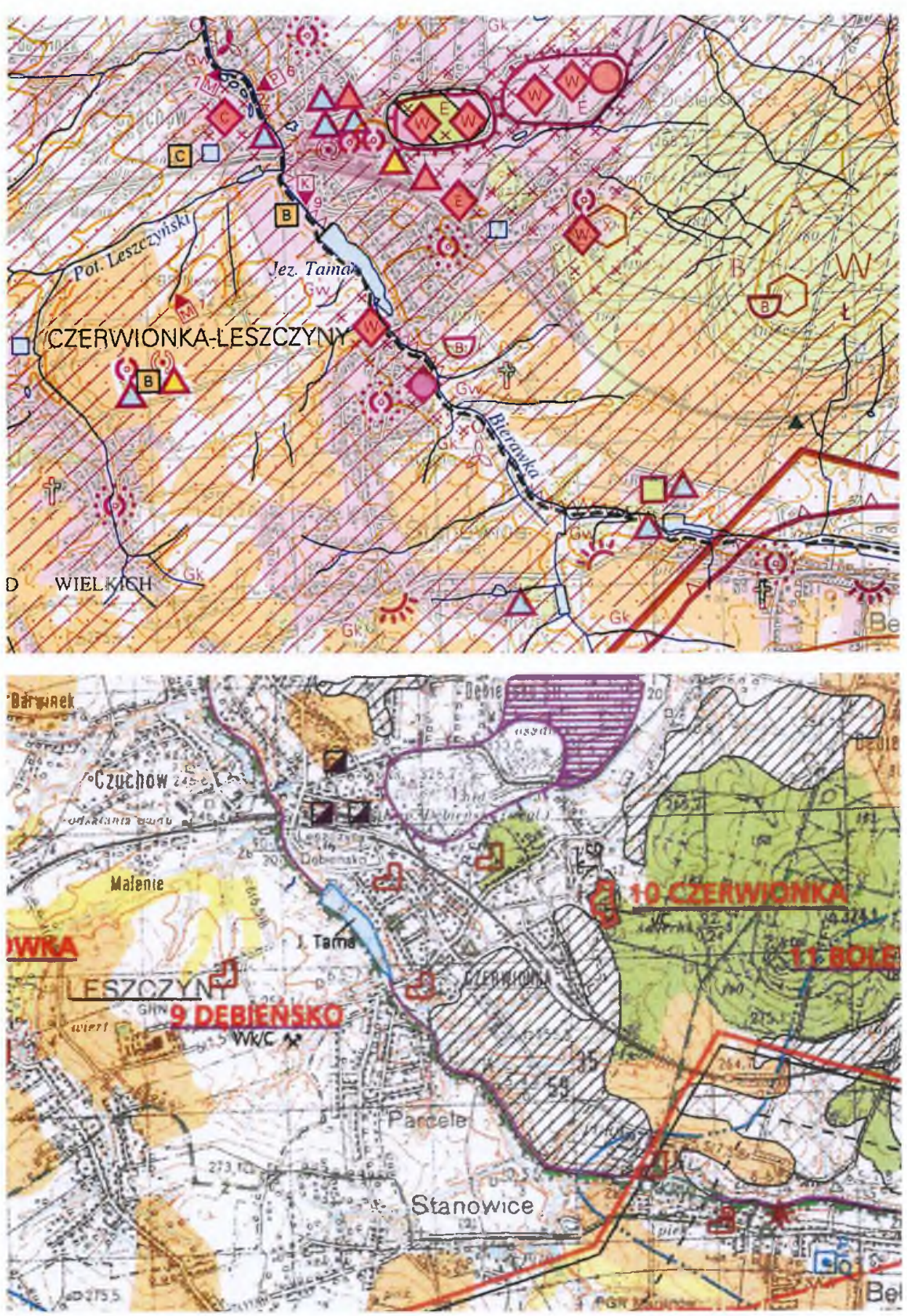

Fig. 5. Excerpts from the Sozological Map of Poland, scale 1:50 000, and the Geological and Economic Map of Poland 1:50 000 
The 1:50 000 scale Sozological Map of Poland (Fig. 5, top) shows various events related to the degradation and protection of the environment; the scope and choice of its contents give the map its comprehensive character. As J. Kondracki wrote (1992), "the map doesn't contain a scientific subject matter ... in contrast to the geomorphological maps. It doesn't represent a typology of the natural environment, but constitutes an inventory of various facts". Already the first glance at the extensive legend of the map with its 160 items allows us to notice a decisive predominance of degrading events (degradation of air, terrain surface, soils, forests, surface and ground waters) and of related events (degradability, degradation prevention, recultivation). The share of events related to the environmental protection in the first version of the map, equal to less than $30 \%$, fell below $20 \%$ with the changes introduced in its current version, published since 1987. These proportions have changed due to the expansion of the part devoted to degradation and due to the omission of the presentation of the mineral deposits which were originally included in the chapter "Environmental protection and protection of natural resources". Adding new items enriched the content. These are, among other things, investments that are particularly oppressive for the natural environment, waste management and localities with sewerage system. Also, more quantitative characteristics appeared, expanding the information on topics presented earlier: relative heights of anthropogenic forms and values of sewage discharge. Certain changes in classification have been also introduced on the map currently published; for instance, the chapter "Degradability of the environment" has been omitted and its content included in the chapter "Degradation of the components of the natural environment", while a classification of lands from the point of view of their development density has been added. Also, the graphics of the map underwent evolution, which improved its readability thanks to, among other things, the adaptation of the structure of some cartographic symbols to the rules of semiotics. The current coverage of the country by the sozological map is equal to about $45 \%$.

The 1:50 000 scale Sozological Map introduced a model — both as regards the scope of its content and its classification - which is worth taking into account when working on other maps of this kind. One can also use symbols used here, but one suspects that it will be a long time before a widely accepted system of symbols will be designed.

In parallel to the work on the Sozological Map of Poland conducted by GUGiK (Head Office of Geodesy and Cartography), research on the state of the natural environment of the country is developed in the State Geological Institute. The result of this research is the 1:50 000 scale Geologicaleconomic Map of Poland and regional geochemical atlases with 1:50 000, 1:100 000 and 1:200 000 scale maps, published since the early 1990s and the 1:2 500000 scale Geochemical Atlas of Poland (1995).

The Geological-economic Map (Fig. 5, bottom) presents some environmental resources, such as mineral deposits, surface and ground waters and 
natural objects protected by the law as well as monuments of cultural heritage, also protected by the law. From more than 200 items forming the legend of the map, almost half are mineral deposits. This is a typically geological content, and the sozological aspect of the map in indicated by the classification of mineral deposits from the point of view of extraction limitation, resulting from the nature protection regulations. The content of the Geologicaleconomic Map coincides to a certain degree with that of Sozological Map as regards the natural environment protection (various types of protected areas) and water degradation (pollution of surface and ground water, depression sinks).

The scope and classification of the content of the 1:50 000 scale Geologicaleconomic Map of Poland underwent several changes, caused by the evolution of the concept of the map and the necessity of adapting its content to the changes in the legal regulations regarding environmental protection. In 2004 the Geological-economic Map became Part A of the 1:50 000 scale Geoenvironmental Map of Poland. Part B is the new thematic layer "Endangerment of the Earth surface - geochemistry of the environment". This includes issues related to waste disposal, as well as the results of research on chemical pollution of soils and water deposits (among other things, heavy metals and organic compounds content), which is an expansion of the subject matter found in the geochemical atlases mentioned earlier (M. SikorskaMaykowska, R. Strzelecki 2001).

Another trend in sozological cartography, but of different character because of its scale distance, develops in school atlases. During the first two decades - starting in the mid-1970s - these were exclusively atlases published by PPWK, which had a monopoly on the market of publications for schools. In these atlases a set of two maps was usually repeated: nature protection and environmental pollution, first included in the Geographical Atlas of Poland of 1974, mentioned in the introduction to this paper, although later it did happen that both issues appeared on the same map. The original scale of the maps, 1:6 000 000, gradually increased to 1:5000 000 and 1:4500 000 . The content devoted to nature protection - originally this consisted of national parks and nature reserves - was enriched as the forms of protection were expanded, controlled by various regulations. Maps of environmental pollution underwent greater changes; but the basis of their content was always inland water and air degradation. The destruction of the soils and a synthetic image of environment degradation were shown less often. A remarkable component of the "sozological equipment" of the PPWK atlases are large-scale maps of the areas of ecological disaster, included since the late 1970s. Despite of the long period of work on sozological maps, in the PPWK atlases no model of graphic form, based in a uniform system of cartographic symbols, was created.

Among other sozological maps in school atlases worth noting is the comprehensive 1:4 000000 scale map "Environmental Pollution" published by the Cartographic Publishing House "Demart", with a larger scope of 
content (among other things, waste, sewage discharge, forest health and many other phenomena of quantitative characteristics) and more original graphics than the earlier projects of this type.

The weakest link of the sozological cartography in Poland are medium. scale, thus general, maps of the country and of the regions. Their small number is related to the fact that regional atlases, where such maps would be best placed, are rarely published. After the regional voivodship atlases from the 1980s, mentioned earlier, worth noting sozological issues can be found only in the Atlas of the Lower and Opole Silesia (1997). Although it does not contain a comprehensive sozological map, the 1:500 000 map "Categories of nature protection" is a good example to be used when working on other projects of this type, both because of the scope of its content and the manner of its presentation. As a model of the comprehensive sozological approach, however, one can regard the 1:750 000 scale unpublished map State of the natural environment of Mazowieckie Voivodship, created as a Master's degree thesis in the Chair of Cartography of the Warsaw University.

\section{REFERENCES}

Brykowicz K., Waksmundzki K., 1970, Kompleksowa mapa zaburzeń i zniszczeń w środowisku geograficznym [Comprehensive Map of Disturbances and Destructions in the Geographical Environment; in Polish]. Problemy, no. 8, pp. 465-477.

Horodyski B., 1983, Problemy prezentacji kartograficznej na mapach so zologicznych w duzych skalach [Issues of Cartographic Presentation on Large-scale Sozological Maps; in Polish], Prace i Studia Geograficzne, vol. 4, , pp. 145-153.

Jankowski A. T., Zieliński J., 1986, Atlasy sozologiczne miast GOP-u jako przykład kartograficznego ujęcia przeobiażeń niektórych elementów środowiska geosystemów miejskich [Sozological Atlases of GOP Cities As an Example of the Cartographic Approach to the Transformations of Some Elements of the Environment of Urban Geosystems; in Polish], [in:] XV Ogólnopolska Konferencja Kartograficzna: Polskie Atlasy Regionalne [15 $5^{\text {th }}$ All-Polish Cartographic Conference Polish Regional Atlases; in Polish], Materiaty Ogólnopolskich Konferencji Kartograficznych, vol. 12, Poznań 1986, pp. 35-42.

Kondracki J., 1992, Mapa sozologiczna 1:50 000 (recenzja) [1:50 000 scale Sozological Map (review); in Polish], Polski Przeglqd Kartograficzny, vol. 24, no. 3, pp. 109-110.

Sikorska-Maykowska M., Strzelecki R., 2001, Geochemia środowiska-propozycja nowej tematyki na Mapie geologiczno-gospodarczej Polski 1:50 000 [Environmental Geochemistry - A Proposal of a New Subject Matter on the 1:50 000 Scale Geologicaleconomic Map of Poland; in Polish], Przeglad Geologiczny, vol. 49, no. 8, pp. 698-701.

English translation: Matgorzata Mikulsha 